\title{
A Critical Review of Airport Privatisation in the Kingdom of Saudi Arabia: Case study of Medina Airport
}

Mohammed Chaouk, Romano Pagliari, Chikage Miyoshi

\begin{abstract}
Saudi Arabia is one of the few Middle-Eastern states to have undertaken an airport privatisation programme. Medina was one of several airports that have been privatised in Saudi Arabia when it was awarded to Tibah Airports in 2012 under a Build-TransferOperate agreement. This paper compares the performance of Medina airport in terms of traffic, revenues, costs and profitability with projections made during the duediligence period prior to the airport's privatisation. We found that the airport benefitted from favourable market conditions post-privatisation which facilitated the attainment of some important achievements with regard to route development and customer service. However, we also found that profitability was lower than forecast during the due-diligence process prior to privatisation and that this was mainly as a result of unexpected interventions by the regulator GACA. We have raised important policy implications for future privatisation transactions, the success of which is crucially dependent on the Kingdom minimising the level of regulatory risk facing potential investors. There are cultural dimensions, human resources strategies and administrative governance issues in addition to the very specific nature of the sociopolitical environment which are all factors that need to be considered in future privatisation transactions.
\end{abstract}

Keywords

Airport privatisation, airport performance, regulatory system, BTO, airport BTO agreement. 


\section{Introduction}

Privatisation of state-owned utilities has its origins in the industrial strategy pursued by the Conservative Government in the UK during the 1980s. Indeed, the first significant airport privatisation was the sale in 1987, through an IPO, of the then British Airports Authority (Doganis, 1992). The perceived success of the first transaction combined with favourable market conditions (spurred largely by strong economic growth and deregulation) and the need to finance capacity expansion, inspired other governments to adopt airport privatisation as an instrument of policy (Ison et al., 2011; Vogel, 2011). The BAA privatisation was followed in the 1990s, by the partial sales of Vienna and Copenhagen extending to much larger scale transactions involving the airport networks of New Zealand, Australia, Malaysia, South Africa, Mexico and Argentina (Forsyth, 2006; Graham, 2011). By 2017, over 600 airports, constituting almost 14\% of airports worldwide, had been either partially or fully privatised. The scale of privatisation has been greater in Europe where $31 \%$ of airports have some form of private sector ownership. Latin America and Asia-Pacific follow with $26 \%$ and $12 \%$ respectively. A very small number of airports have been privatised in Africa, the Middle East and North America (ACI, 2017). Although the majority of airports today are still publicly-owned, it is expected that in future, more governments will continue to adopt the privatisation model spurred largely by the perceived benefits (Graham, 2011; Rikhy et al., 2014). Humphreys (1999) found that governments can benefit from privatisation by enabling airports to access capital markets to finance capacity expansion, obviating the need for state subsidy. Airport privatisation can also improve efficiency and financial performance (Forsyth, 2002), quality of service (Hooper et al., 2000) and management structure Assaf (2010). While the financial gains that could potentially accrue to the state from the sale of airport assets can also act as an important motive to pursue a privatisation programme (Niemeier, 2002).

The impact of airport privatisation, as reported in the literature, appears to have been generally quite positive. According to Oum et al. (2006) privatisation has achieved higher efficiencies in Europe. Chen et al. (2017) argue that improved techno-economic efficiency has been achieved by privatised airports in Europe and Asia-Pacific. Barros and Dieke (2007) concluded that efficiency is higher in privately owned airports in Italy compared to those under public ownership. Perelman and Serebrisky (2012) 
found that private airports in Latin American countries are generally more efficient than those under public ownership.

The scale of airport privatisation in the Middle-East region, in contrast to Europe, has been quite limited. In addition to Saudi Arabia, which is the main focus of this paper, airports have been privatised in Jordan, Egypt and Oman. In the case of Oman, the privatisation experience was short-lived. A private consortium secured a 25 yearsconcession contract to manage Oman's airports in September 2001. However, in 2004, one consortium member, BAA, decided to pull out of its commitment after failing to reach an agreement with the state over the expansion of Seeb Airport (Ali, 2004). Amman's new Queen Alia International Airport, built in 2007 is managed by a publicprivate consortium under a 25-year BOT agreement.

Saudi Arabia has been the most active in privatising its airports. This paper aims to review the impact of the privatisation on the operational and financial performance of Medina airport. We provide an overview of the Kingdom's economy and recent policy developments in the airport sector in sections 2 and 3. In Section 4, we describe Medina Airport's operating characteristics followed by a commentary on the regulatory framework and privatisation process that was adopted by Saudi Arabia. We review the operational and financial impacts of privatisation on Medina Airport in section 6 while the paper concludes with a discussion in Section 7.

\section{Saudi Arabian Economy}

Accounting for $22 \%$ of the world's oil reserves has enabled Saudi Arabia's to achieve the fastest growth of any economy since the 1970s (OPEC, 2017). This oil dividend has provided the volume of funds to not only finance and support other sectors of its economy (i.e. defence) but also to supply aid to neighbouring economies in the Middle East and other regions (Alkhathlan, 2013). Despite price fluctuations over the past 40 years, the oil sector still accounts for approximately $90 \%$ of export revenues and $45 \%$ of gross domestic product (GDP) (General Authority for Statistics, 2016). This dependency on oil does, however, make it vulnerable to the effects of adverse movements in price. In recognition of this reality, the government recently set out a plan to reduce oil-dependency in a new national strategy titled "Vision 2030" which seeks to support greater diversification by introducing reforms designed to galvanise other sectors of the economy such as tourism, education, health and manufacturing. 
Saudi Arabia's population in 2016 was reported to be 31.4 million of which $37 \%$ are non-nationals. The majority of the population are mainly concentrated around Makkah, Riyadh (the capital) and the Eastern Province (Figure 1). In the same year, the GDP of Saudi Arabia amounted to US $\$ 653.2$ billion. This corresponds to a GDP per capita of US $\$ 20,813$; a rank of $34^{\text {th }}$ globally and $5^{\text {th }}$ in the Middle East (World Economic Forum, 2016).

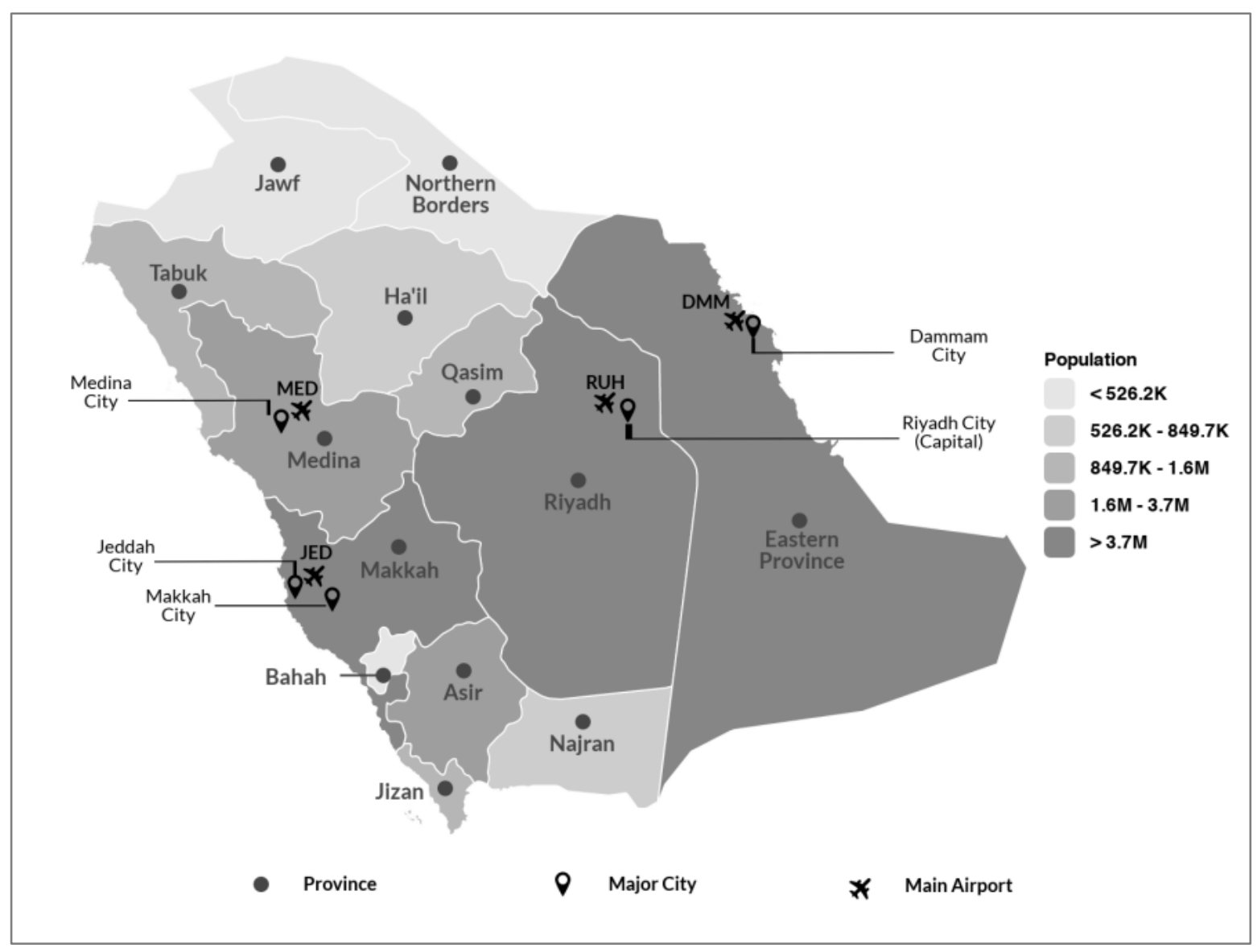

Figure 1 Major cities, main airports, and population distribution by provinces of Saudi Arabia

Source: General Authority for Statistics (2016)

Saudi Arabia has a long coastal area adjacent to the Red Sea and Gulf Sea. It shares land borders with Jordan, Iraq, and Kuwait in the north, United Arab Emirates, Qatar, Bahrain in the East and with Oman and Yemen in the South. Saudi Arabia is also the home of the two holiest sites of the Muslim Faith, Makkah and Medina, where millions of its adherents arrive every year to perform religious Pilgrimage ${ }^{1}$.

\footnotetext{
${ }^{1}$ Islamic Pilgrimage, or Hajj, is a mandatory duty in the Islamic Religion which should be carried out at least once in the lifetime of a Muslim adult. Umrah is another form of pilgrimage to Mecca which can be performed anytime during the year.
} 


\section{Saudi Arabia's Airports}

There are 6 international, 8 regional and 13 domestic airports in Saudi Arabia and these are all listed in Table 1 in addition to their respective 2015 traffic volumes. The locations of the four largest international airports are shown in Figure 1.

Saudi Arabia has achieved high air traffic growth in recent years. This has in part been due to the effects of liberalisation which has permitted the competitive entry of new low cost airlines to rival state-owned Saudi Arabian Airlines' domination of the domestic market. In 2015, the airport system handled 81.8 million passengers, a 96\% increase on 2007 (GACA, 2008; GACA, 2015).

Table 1 Traffic Handled by Saudi Arabian Airports in 2015

\begin{tabular}{lcccc}
\hline Airport & IATA Code & Air Transport Movements & Passengers & Cargo (kg) \\
\hline Jeddah & JED & 212,799 & $30,093,539$ & 716,610 \\
Riyadh & RUH & 172,754 & $22,545,296$ & 328,505 \\
Dammam & DMM & 84,803 & $9,407,304$ & 95,321 \\
Medina & MED & 48,296 & $6,306,222$ & 10,728 \\
Abha & AHB & 27,095 & $3,115,068$ & 2,982 \\
Tabuk & TUU & 11,694 & $1,310,519$ & 1,711 \\
Taif & TIF & 10,091 & $1,157,188$ & 403 \\
Al-Gassim & ELQ & 13,670 & $1,443,711$ & 846 \\
Hail & HAS & 6,815 & 800,982 & 1,110 \\
Gazan & GIZ & 13,505 & $1,735,775$ & 2,907 \\
Al-Baha & ABT & 3,205 & 377,532 & 102 \\
Wadi Dawaser & WAE & 1,885 & 111,468 & 8 \\
Sharurah & SHW & 2,347 & 202,293 & 115 \\
Turaif & TUI & 1,020 & 62,968 & 33 \\
Bisha & BHH & 3,653 & 376,791 & 123 \\
Ar'ar & RAE & 2,374 & 240,822 & 363 \\
Wedjh & EJH & 1,122 & 63,651 & 20 \\
Rafha & RAH & 1,182 & 70,396 & 33 \\
Nejran & EAM & 1,989 & 227,232 & 171 \\
Al-Qaisumah & AQI & 2,192 & 138,650 & 90 \\
Al-Jouf & AJF & 4,623 & 450,505 & 567 \\
Al-Ahsa & HOF & 7,511 & 408,780 & 425 \\
Al-Gurayat & URY & 1,908 & 207,437 & 310 \\
Yanbu & YNB & 9,238 & 960,144 & 209 \\
Al-Ula & ULH & 474 & 23,128 & 1 \\
Dawadami & DWD & 416 & 23,471 & 2 \\
Rabigh & - & 32 & 81 & 0 \\
\hline TOTAL & & $\mathbf{6 4 6 , 6 9 3}, \mathbf{8 6 0 , 9 5 3}$ & $\mathbf{1 , 1 6 3 , 6 9 5}$ \\
\hline
\end{tabular}

Source: GACA (2015)

The top four airports account for $84 \%$ of the Kingdom's total traffic volume. Jeddah is the Kingdom's commercial capital and its airport also serves pilgrimage traffic to and from the holy sites at Makkah. Riyadh airport serves the capital city while Dammam 
serves traffic driven largely by activities related to oil fields located in the Eastern Province. Medina hosts the second holiest religious sites and receives, like Makkah, considerable volumes of pilgrimage traffic.

IATA forecasts that traffic in Saudi Arabia will increase by 4.1\% per annum, the third highest in the Middle East, behind Qatar (5.9\%) and United Arab Emirates (4.1\%), and higher than the average growth per annum of Europe (2.5\%), North America (2.8\%), and Latin America (3.8\%) (IATA, 2016). This expectation has created an urgency around the need to accelerate the delivery of new investment in order to enable the airport system to cope with both immediate capacity bottlenecks and to accommodate future growth.

Historically, all the airports in the Kingdom were owned and operated by the government through the General Authority for Civil Aviation (GACA). As well as owning airports, GACA was and still remains the designated regulator of air transport in the Kingdom. In 2007, at the behest of the Government, GACA undertook an initial phase of airport privatisation using various public-private partnership models, deploying a mix of relatively short-term limited scope management contracts and larger more extensive project finance / BTO transactions. In 2007, investors were invited to participate in a competitive tender to operate management contracts at the airports of Jeddah, Riyadh and Dammam.

The German airport company, Fraport, secured a 6-year management contract in 2008 to operate both Jeddah and Riyadh airports. Both airports were subsequently transferred back to full GACA control in 2014. The scope of these management contracts was relatively limited with Fraport supplying both airports with a range of technical and advisory services (Fraport, 2014).

Separately, at Jeddah, in 2011 GACA awarded a 20-year BTO contract to a consortium led by the Bin Laden Group and Aéroports de Paris to expand, refurbish and manage the Hajj terminal. The two other terminals (North and South) are currently in the process of being replaced by two new terminals also being built by the Bin Laden Group at a cost of US \$7.5 billion. In April 2017, GACA awarded a 20-year management contract to a consortium comprising of Changi Airport Group and Saudi Naval Services to manage airside operations and the newly built Terminals. However, the contract was abruptly terminated by GACA in February 2018 following an internal 
review which raised some important concerns as stated in the official statement issued by GACA (GACA, 2018).

At Riyadh, Fraport operated a management contract between 2008 and 2014. GACA then assumed full control. In February 2016, GACA awarded a management contract to ARI, a subsidiary of the Irish-owned Dublin Airport Authority to operate the newly constructed Terminal 5 .

In 2008, Changi Airport Group secured a six-year contract to co-operate with GACA in the management of Dammam; this was extended by one year in 2015. The airport is now under the full control of GACA with continued technical advisory support being provided by Changi Airport Group.

Medina Airport was privatised in 2012. The Turkish airport operator, TAV, led the Tibah consortium (a joint venture between the Turkish company TAV Airports and two Saudi national companies, Saudi Oger and Al-Rajhi Holding Group) that was successful in winning the tender for a 25-year BTO contract to manage the airport (Youssef, 2013). Tibah Airports Operations Co. Ltd paid US\$249 million to GACA as winners of a competitive tendering process to secure the rights to manage the airport. Table 2 Privatised Airports in Saudi Arabia (Current Situation)

\begin{tabular}{lllll}
\hline Airports / Terminal & Types of Contract & Year & Period & Operator \\
\hline Medina & BTO & 2012 & 25 Years & Tibah \\
Riyadh (Terminal 5) & Management Contract & 2016 & 5 Years & ARI \\
Jeddah (Hajj Terminal) & BTO & 2007 & 15 Years & Bin Laden \\
Jeddah & Management Contract & 2017 & 20 Years & CAG \\
\hline
\end{tabular}

Source: Compiled by author from various sources

\section{Medina Airport}

Prince Mohammad bin Abdulaziz International Airport is located close to the city of Medina; home of the Muslim World's second holiest site. This is where the Prophet Muhammad is buried. Pilgrims who arrive for Hajj or Umrah by air can enter the Kingdom via two entry points only, with Medina Airport being one of them. Medina is also the destination of Muslims in the Umrah Season, which extends throughout the year and reaches its peak in the month of Ramadan. 
Before it was transformed into an international airport in 2012, Medina Airport had been facilitating the access of pilgrims to the Holy City either through domestic services or through a limited volume of international flights scheduled during the Hajj season. Limitations on the number of Hajj flights using Medina was set by GACA. Hajj traffic makes Medina Airport the fourth busiest in KSA behind the international airports of Jeddah, Riyadh and Dammam (GACA, 2010). The airport is an important asset to the local economy which depends heavily on inbound religious tourism (Youssef, 2013).

In 2007, the airport reached its maximum capacity of three million passengers per year. GACA's attempts to implement a 2006 master plan which included a new terminal had become increasingly frustrated by bureaucratic constraints and funding limitations. The opportunity to privatise the airport was further complicated by resourcing challenges largely driven by the underutilisation of the airport's employees and facilities outside of the pilgrimage seasons; in 2012, traffic during the Hajj season represented $38 \%$ of the total volume for that year (Tibah, 2012).

However, two important reforms were subsequently undertaken which helped pave the way for the airport's privatisation. Firstly, GACA adopted ICAO's principle of full cost recovery with regard to capital investments, which allowed for increased aeronautical charges to be levied on international passengers at Medina Airport. In addition, the Government introduced a new one-way travel policy which permitted passenger arrivals at Jeddah followed by departures from Medina and vice versa (Youssef, 2013). The latter reform played a role in increasing the traffic outside Hajj season. In 2016, the share of Hajj season represented 11\% from the total traffic for that year (Tibah, 2016).

The airport handled 7.8 million passengers in 2017, of which 70\% was domestic and $30 \%$ international. The largest carrier at Medina is Saudi Arabian which accounts for $45 \%$ of scheduled seating capacity; Turkish airlines is the second most important accounting for $10 \%$. The largest low-cost carrier serving the airport is Flynas which supplies $6 \%$ of total scheduled seating capacity at the airport (CAPA, 2018). Overall, low cost carriers account for $14 \%$ of total seats supplied at Medina (CAPA, 2018). The top three destinations are: Riyadh, Jeddah and Istanbul. 


\section{Medina Airport privatization process}

It had become apparent that existing facilities at the airport would not be sufficient to cope with future traffic volumes given the state's intention to remove restrictions on religious tourism and plans to further liberalise the domestic airline market. In 2009, GACA, with the help of the International Finance Corporation, started the process of preparing the airport for privatisation. The model that they agreed on was to be based on a 25-year BTO concession contract. For this purpose, GACA set its minimum technical requirements (MTRs) for the project, which included the setting of operating procedures and required service levels that private operators would be expected to meet. The qualified bidders were invited in March 2010 to submit their bids. A series of discussions took place in the following months between each bidder and GACA. Eventually, out of the eight qualified bidders, four were shortlisted: Malaysian Airports (Malaysia), Houston (USA), Aéroports de Paris (France) and Tibah (Turkey).

A scoring system was used to evaluate each bid where both technical and financial proposals were allocated equal weight. Under the financial proposals, bidders were expected to declare the bid price they would be prepared to pay to win the contract and the proportion of operating revenues they would be expected to share with GACA over the lifetime of the BTO contract. The technical proposal incorporated all non-financial aspects including proposed investments, design solutions and service standards. The bid achieving the highest score would be awarded the concession contract (Youssef, 2013).

The concession contract was finally awarded to Tibah Airports, a consortium consisting of the Turkish operator, TAV Havalimanlari Holding, and the Saudi companies, Al Rajhi Holdings Group and Saudi Oger Limited. TAV was an established airport concessions operator with extensive experience in both airport and related service company management both in Turkey and across the Middle-East, Balkan and North African regions. In October 2011, the concession contract was signed between GACA and Tibah and in June 2012, the airport handover was completed (TAV, 2011). Under the terms and conditions of the BTO contract, Tibah was committed to: delivering a new 158,000 $\mathrm{m}^{2}$ fully air-conditioned passenger terminal, a new 90,000 $\mathrm{m}^{2}$ Hajj terminal, extending the existing runway, building new taxiways, airfield lighting systems, aprons, access roads and parking facilities. These projects were 
expected to be delivered over a 3-year period at a cost of US\$1.14 billion. In return for the rights and obligations stipulated in the contract, Tibah was required to transfer $54.5 \%$ of the annual turnover of its Media operations to GACA in the form of a concession fee.

\section{Table 3 Contract structure and requirements for Medina Airport}

Concession Type

Concession Duration

Construction Duration

Capital Investment

Concession Fee
Build-Transfer-Operate (BTO)

25 years starting 2012

Up to 3 years

US\$1.14 Billion

$54.5 \%$ of Gross Revenues per calendar year must be paid to GACA

Source: Medina Airport BTO Agreement

\section{Medina Airport privatization outcomes}

\subsection{Traffic}

Figure 2 below compares forecast and actual air transport movement volumes at Medina over the period 2010 to 2016. Tibah forecasted a decline in traffic between 2011 and 2012 due mainly to the effects on volume of imposing operating restrictions designed to facilitate runway construction work. However, traffic volumes over the entire period actually exceeded expectations. On average, over the period, air transport movement volumes were under-estimated by a factor of $57 \%$.

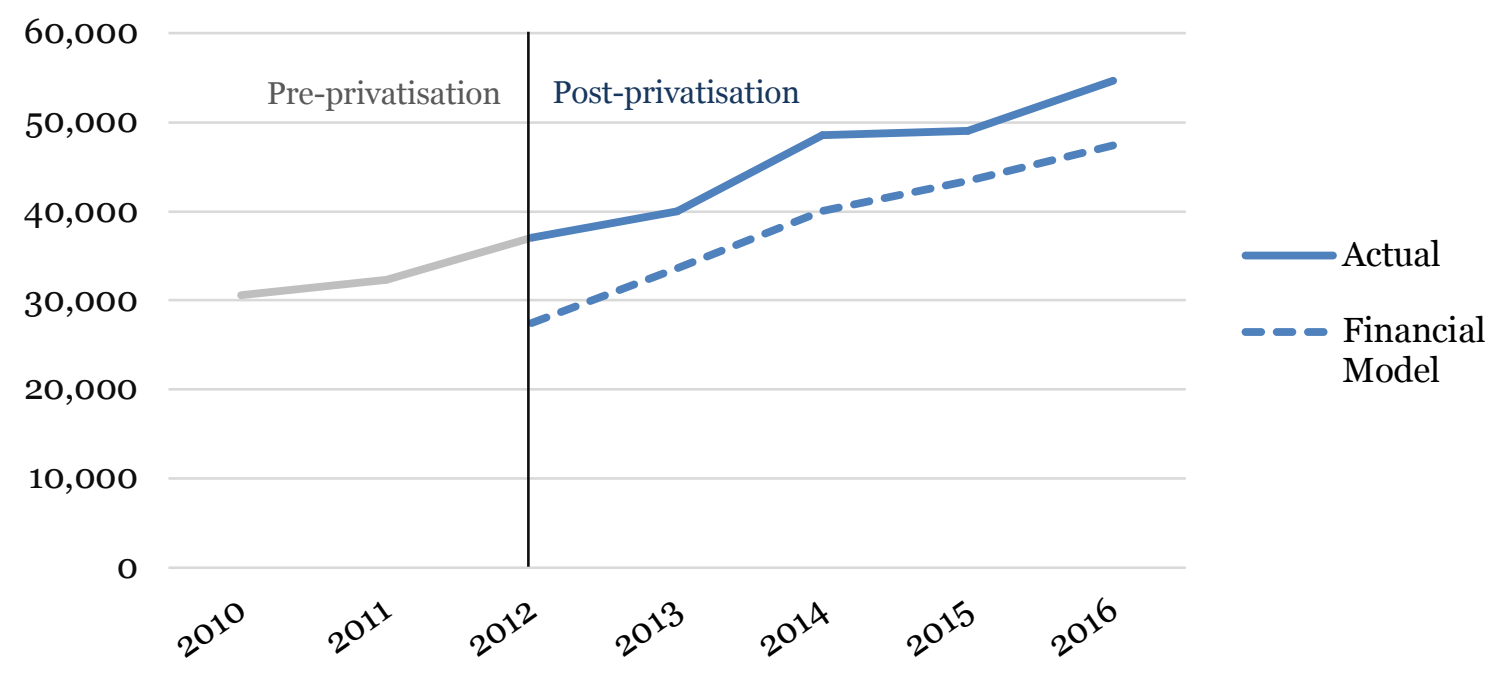

Figure 2 Medina Airport's air traffic movements from 2010 to 2016 actual and financial model

Source: Compiled by Author from Tibah Airports Co. LTD unpublished yearly reports

Passenger traffic volumes similarly exceeded expectations. Prior to privatisation, between 2005 and 2012 passenger traffic on average was growing at a rate of 10\% per 
year. This accelerated to an average annual rate of $14 \%$ in the years following privatisation. By 2016, Medina was handling an annual throughput of 6.5 million passengers with connections to 203 destinations. Following privatisation, the number of destinations increased significantly, by almost $20 \%$, to reach 242 by 2016. Leading markets in terms of passenger traffic in 2013 were: Egypt, Turkey, UAE, Indonesia and Iran. Between 2013 and 2016 additional routes were added to airports in Turkey while there was a significant decline in traffic to and from Iran due to the cancellation of air traffic rights. These traffic losses were more than compensated for by significant improvement in volumes on routes to Egypt, Pakistan and Malaysia (Table 4).

Saudi Arabian Airlines accounts for the largest share of the international passenger market at Medina followed by Turkish Airlines and Egypt Air. However, there was a decrease in the percentage shares of international passengers carried by Saudi Arabian Airlines from $38 \%$ in 2013 to $27 \%$ in 2016. Table 5 lists the top ten airlines operating to Medina in terms of the percentage of international passengers in both 2013 and 2016.

Table 4 Medina Airport's destination ranking by PAX in 2013 and 2016

\begin{tabular}{|c|c|c|c|c|}
\hline \multirow[b]{2}{*}{ Rank } & \multicolumn{2}{|c|}{2013} & \multicolumn{2}{|c|}{2016} \\
\hline & Country & Pax & Country & Pax \\
\hline 1 & Egypt & 372,939 & Turkey & $2,160,060$ \\
\hline 2 & Turkey & 370,857 & Egypt & $1,971,064$ \\
\hline 3 & UAE & 233,491 & UAE & $1,601,734$ \\
\hline 4 & Indonesia & 136,713 & Pakistan & $1,130,012$ \\
\hline 5 & Iran & 103,489 & Indonesia & 844,702 \\
\hline 6 & Jordan & 91,230 & Algeria & 665,907 \\
\hline 7 & Malaysia & 85,814 & Qatar & 470,218 \\
\hline 8 & Algeria & 67,395 & Malaysia & 367,036 \\
\hline 9 & Qatar & 56,989 & India & 336,409 \\
\hline 10 & Pakistan & 12,428 & Jordan & 328,122 \\
\hline
\end{tabular}

Source: Compiled by Author from Tibah Airports Co. LTD unpublished yearly reports

There was also an increase in the number of airlines serving the airport; from 51 in 2012 and 59 in 2016. The increase was mainly accounted for by low cost carriers, offering connections to new markets in Turkey, Iran and Asia; this was largely as consequence of the airport's route development strategy which was geared to focussing on tapping additional growth from regions where higher concentrations of Muslim populations reside. 


\begin{tabular}{lclc}
\hline Airline & $\begin{array}{c}\text { Int'l Passengers Market Share } \\
\text { \% in 2013 }\end{array}$ & Airline & $\begin{array}{c}\text { Int'l Passengers } \\
\text { Market Share \% in } \\
2016\end{array}$ \\
\hline Saudi Arabian & $37 \%$ & Saudi Arabian & \\
Airlines & $12 \%$ & Airlines & $27 \%$ \\
Turkish Airlines & $10 \%$ & Turkish Airlines & $11 \%$ \\
Egypt Air & $6 \%$ & Egypt Air & $10 \%$ \\
Emirates Airline & $4 \%$ & Emirates Airline & $7 \%$ \\
Flynas & $3 \%$ & Flynas & $7 \%$ \\
Air Algerie & $3 \%$ & Pakistan Airlines & $5 \%$ \\
Pakistan Airlines & $2 \%$ & Qatar Airways & $4 \%$ \\
Atlas Jet & $2 \%$ & Air Algerie & $2 \%$ \\
Qatar Airways & $2 \%$ & Garuda Indonesia & $2 \%$ \\
Royal Jordanian & $20 \%$ & Royal Jordanian & $2 \%$ \\
Others & & Others & $22 \%$ \\
\hline
\end{tabular}

Source: Compiled by Author from Tibah Airports Co. LTD unpublished yearly reports

Furthermore, following the completion of construction works for the new runway and taxiways in 2014, Medina Airport's Aerodrome Reference Code was upgraded to $4 \mathrm{~F}$, which provided capability to accommodate A380-800 aircraft. Currently, Malaysian Airlines and Emirates are operating their A38os to Medina Airport.

A comparison of passenger traffic and aircraft movements from 2012 to 2016 in the 4 largest international airports in Saudi Arabia was done to understand if the growth achievements were unique to Medina, or similar to other airports in the country regardless of ownership type. Figure 3 does indeed confirm that at least in terms of passenger growth, three out of the four principal Saudi international gateways experienced growth of a similar scale.

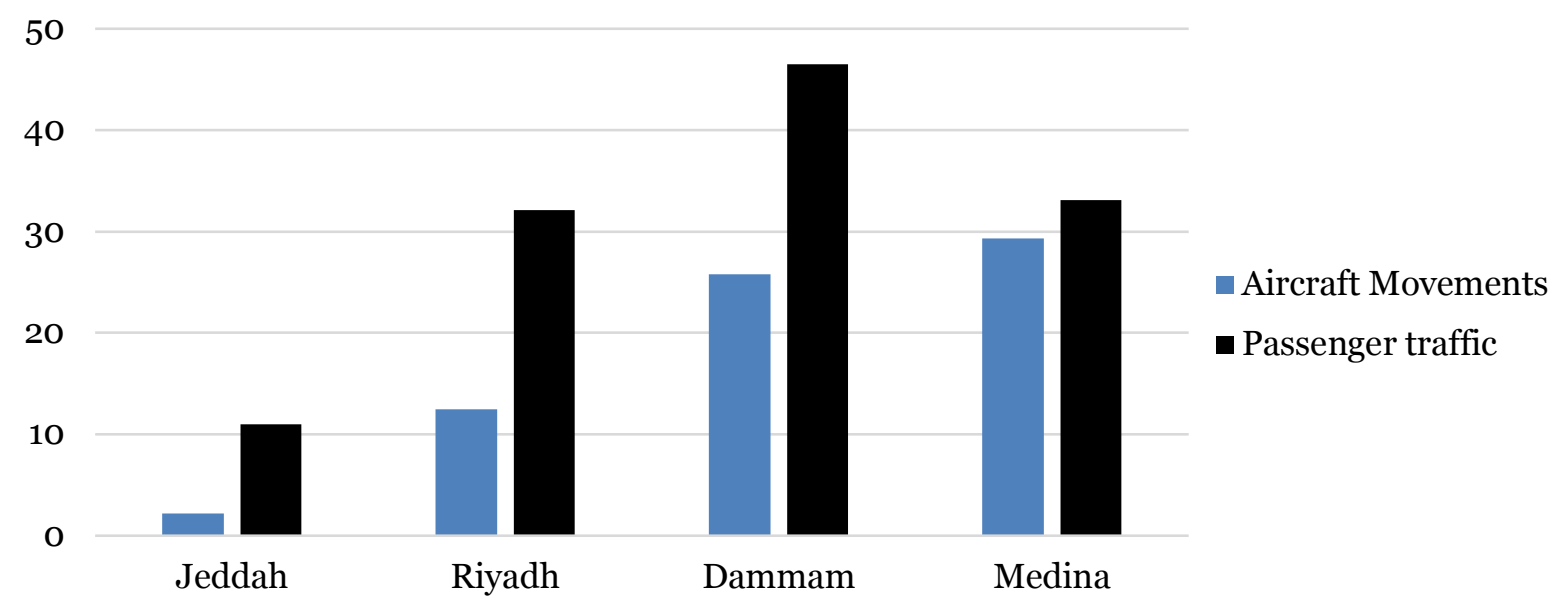

Figure 3 \% growth in aircraft movements and passenger traffic between 2012 and 2016 at Jeddah, Riyadh, Dammam and Medina airports

Source: Compiled by Author from Tibah Airports Co. LTD unpublished yearly reports 
In aircraft movement terms, only Dammam comes close to matching Medina's performance. This suggests that to a fairly significant extent, general market conditions played a considerable role in accounting for traffic growth in addition to the airport's own route development initiatives.

\subsection{Financial performance}

In comparing actual financial performance with that predicted by their due-diligence model, we evaluate operating revenues, operating costs and profitability.

\subsubsection{Operating revenues}

Over the period of analysis, Medina's operating revenues exceeded those projected by Tibah's due-diligence financial model (Figure 4). The margin of error was relatively modest at a scale of approximately $5 \%$ per year (Tibah, 2012). This under-estimation was most likely due to the effect of higher than projected traffic volumes on operating revenues. In addition, what also transpires over the period is that a greater proportion of the airport's operating revenues have been generated from non-aeronautical sources. Figure 5 shows that aeronautical revenues as a proportion of total operating revenues declined from $92 \%$ in 2014 to $83 \%$ in 2016 , a considerable transformation achieved in a relatively short time-frame.

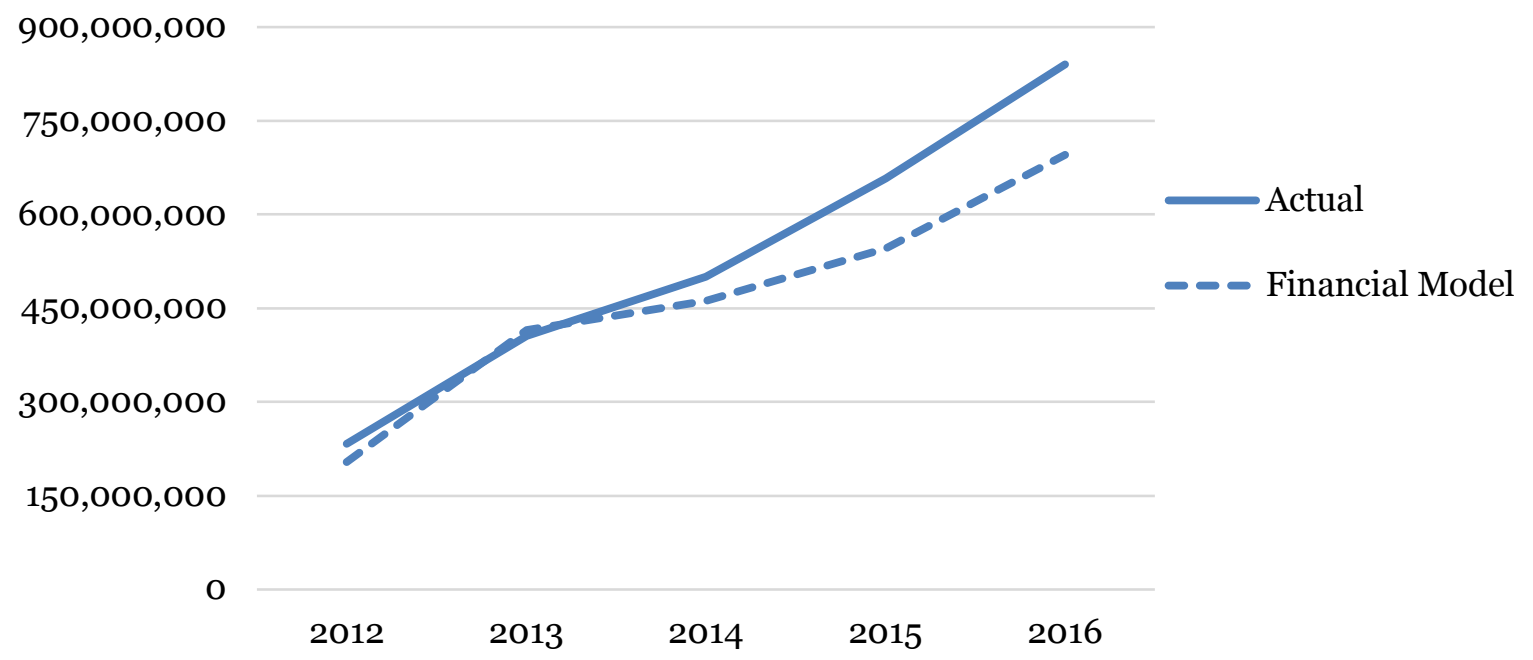

Figure $4 \%$ Actual and Model Operating revenues (in SAR) generated by Medina 20122016

Source: Compiled by Author from Tibah Airports Co. LTD unpublished yearly reports

Indeed, the scale of under-development in commercial revenues prior to 2015 was quite apparent, given the size of the airport, especially when compared to airports of a 
similar size in other regions that appear much better able to generate higher proportions of their revenues from non-aeronautical sources.

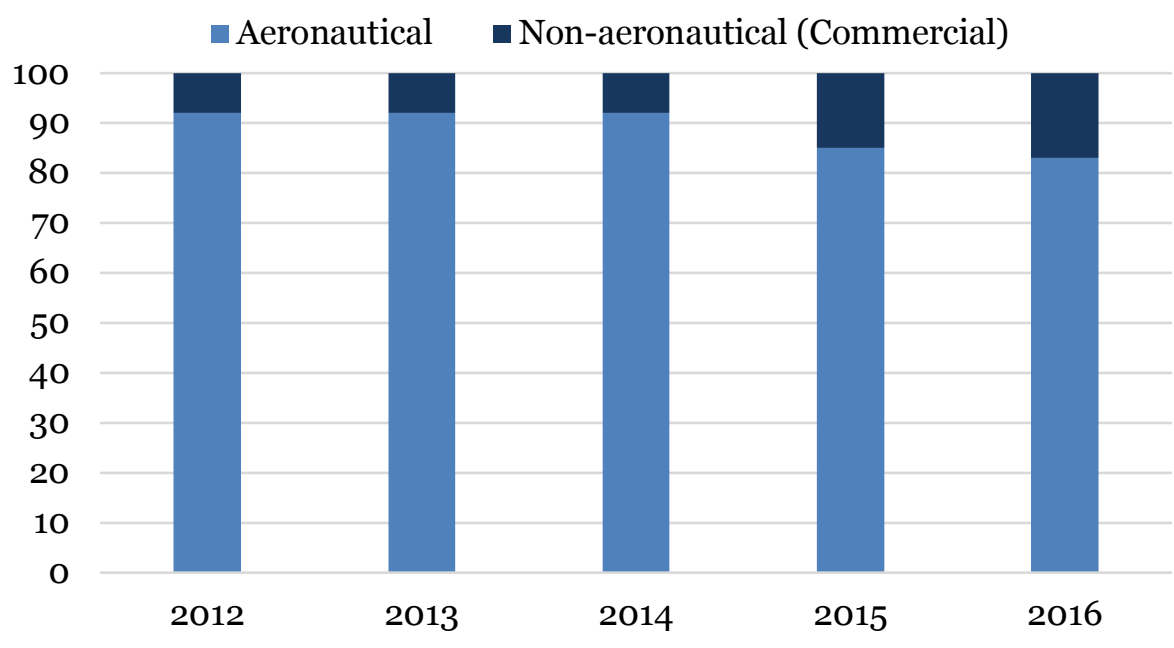

Figure $5 \%$ breakdown in operating revenue from aeronautical and non-aeronautical sources at Medina 2012-2016.

Source: Compiled by Author from Tibah Airports Co. LTD unpublished yearly reports

According to ACI (2013), airports handling in the region of 1 to 5 million passengers annually on average generated $35 \%$ of total operating revenue from commercial sources. Medina's success post-2015 coincided with the opening of the new terminal in 2015, an important deliverable in its BTO contractual obligations. The new building, designed with a much greater incorporation of design features geared to improving retail sales performance, accounts for the significant improvement in commercial yield (Figure 6). However, this is still relatively low by international standards and it is more likely that other factors appear to have had an inhibiting effect on sales.

Although total revenues exceeded projections, Tibah faced an unexpected intervention by GACA in relation to its plan to charge third-party operators turnover-based concession fees on their business operations at the airport. Prior to the transfer of ownership, Tibah had been assured that they would have authority to collect these fees from ground handling, cargo and in-flight catering concessions licensed at the airport; this assumption formed an important element in its due-diligence financial modelling. Table 6 lists those charges approved by GACA prior to the signing of the BTO contract. However, following the sale, GACA agreed to approve only one concession fee (for ground handing) at a reduced rate of US\$0.26 per passenger compared to US\$0.66 which, according to Tibah, had been approved during the due-diligence process. As a result of this unexpected intervention by GACA, the shortfall in revenues was predicted 
to cost Tibah approximately US $\$ 355$ million over the life of the concession agreement (see Table 6)

Table 6 Medina Airport's unapproved concession charges (in US\$)

\begin{tabular}{|c|c|c|c|}
\hline & \multicolumn{3}{|c|}{ Revenue Source } \\
\hline & Ground Handling & Cargo & In-flight catering \\
\hline GACA Approved charges (pre-sale) & 0.66 per $\operatorname{Pax}$ & 5.86 per tonne & $\begin{array}{l}\text { 1.03 per } \\
\text { international } \\
\text { departing } \\
\text { passenger }\end{array}$ \\
\hline GACA Approved charges (post-sale) & 0.26 per Pax & $\mathrm{n} / \mathrm{a}$ & $\mathrm{n} / \mathrm{a}$ \\
\hline $\begin{array}{l}\text { Potential loss of revenue to end of } \\
\text { concession }\end{array}$ & 159 million & 2.9 million & 193 million \\
\hline
\end{tabular}

Source: Unpublished Tibah Airports Co Ltd. LTD letters to GACA

Figure 6 shows the ratio of actual to model aeronautical and non-aeronautical revenues from 2012 to 2016. Actual aeronautical revenue exceeds that forecasted by the model over the period; this is largely the result of under-estimation in their traffic forecasts. Non-aeronautical revenue performance was worse than expected prior to 2015; this may have been mainly a consequence of GACA's intervention with regard to Tibah's proposed third-party concession fees. In both 2015 and 2016, the airport's revenue performance was particularly robust; this was especially so with regard to non-aeronautical business operations where model forecasts were exceeded by a factor of $35 \%$.

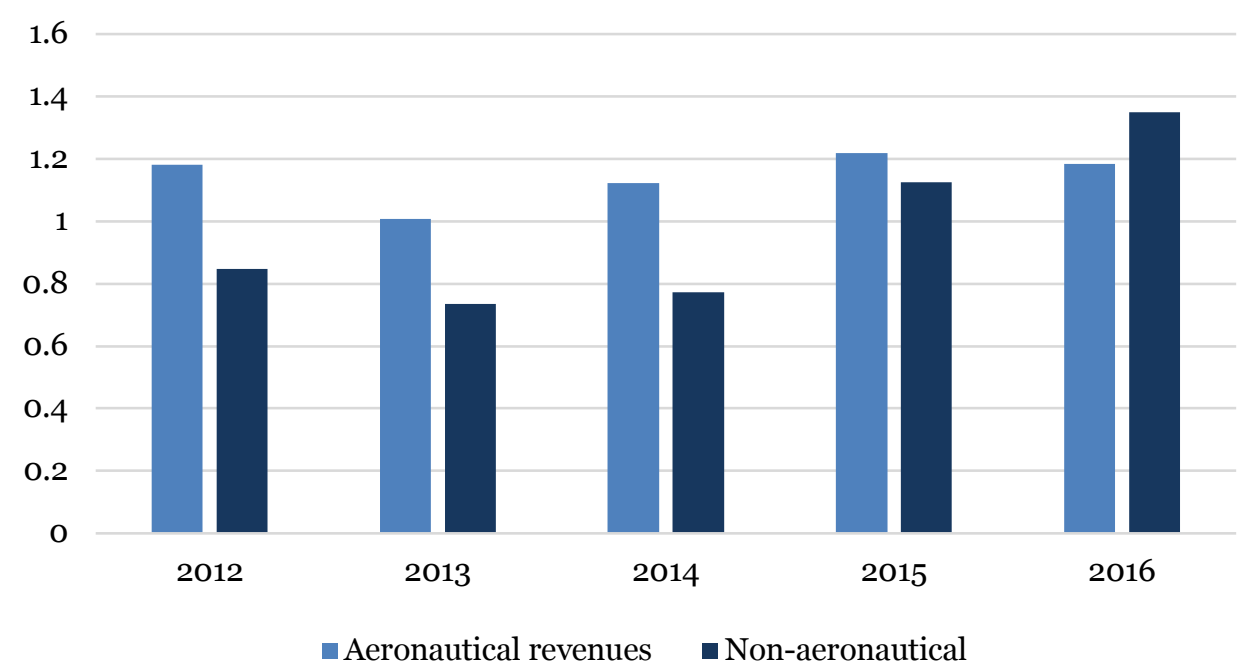

Figure 6 Ratio of actual to model aeronautical and non-aeronautical revenues at Medina 2012-2016.

Source: Compiled by Author from Tibah Airports Co. LTD unpublished yearly reports 


\subsubsection{Operating expenditure}

Over the period 2012 to 2015 the level of operating expenditure incurred by the airport was $46 \%$ higher than forecast (Figure 7). This was as a result of three important developments that were not anticipated prior to the transfer of management responsibility to Tibah.

After having secured the rights to manage Medina Airport in 2012, Tibah was obliged to absorb additional expenditure relating to a secondment agreement with GACA. This involved a requirement to retain highly remunerated GACA's employees who had been employed at the airport prior to privatisation. The expectation was that they would continue to be employed at Medina until the opening of the new terminal, when they would be given the option to either transfer to Tibah employment terms and conditions or to resign from their posts. Shortly after GACA's employees were seconded to Tibah, the organisation's legal status changed to that of an independent public authority.

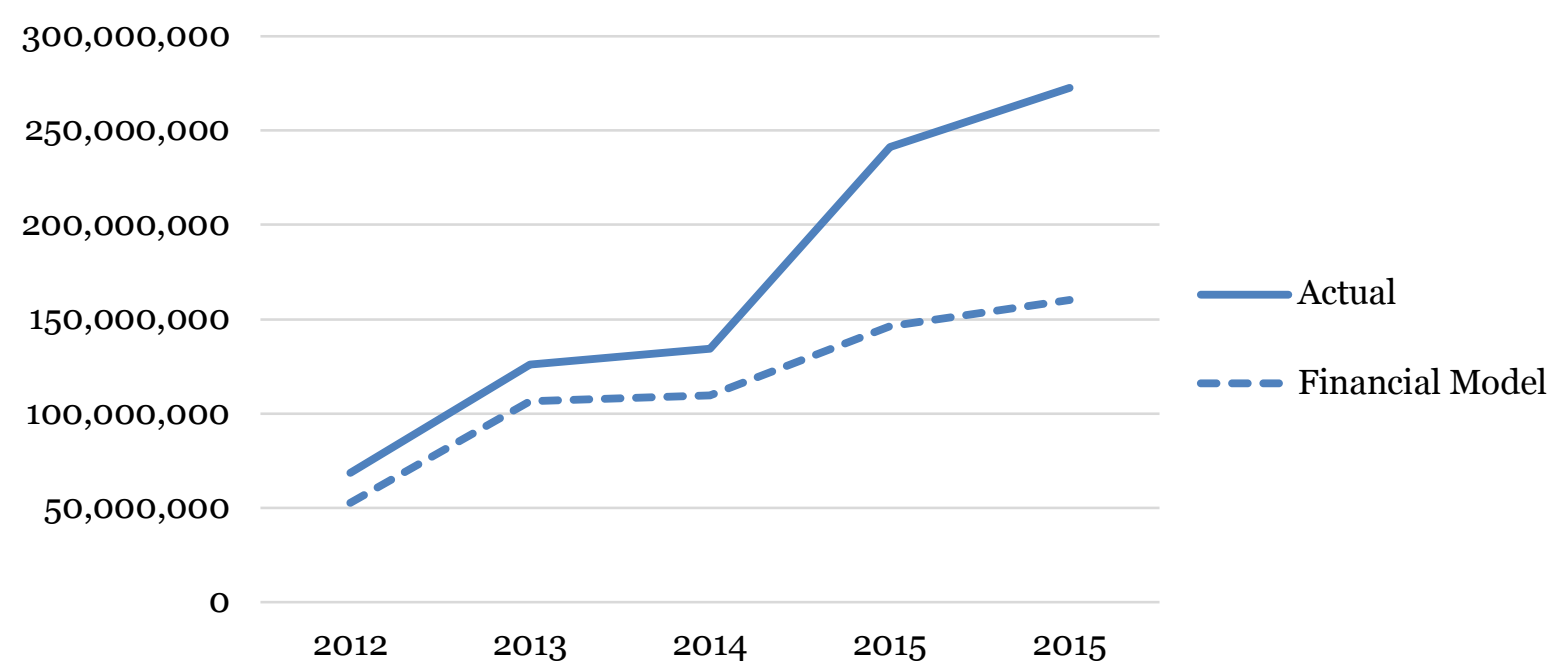

Figure 7 Actual and model operating expenditure (in SAR) incurred by Medina from 2012 to 2016

Source: Compiled by Author from Tibah Airports Co. LTD unpublished yearly reports

The change of legal status meant that there was now a requirement on GACA to raise the salaries substantially not only of its own employees but also of those seconded to Tibah. Tibah were not compensated for this unexpected development and had to bear the additional costs in full. Furthermore, at the end of the secondment agreement, GACA instructed airport management to increase the salaries of those employees who 
had chosen to remain with Tibah by a factor of $15 \%$ as compensation for leaving GACA to join a private sector organisation.

The secondment agreement had also resulted in an increase in the number staff employed at the airport. The financial model had initially assumed that the airport would require 242 employees; up to 2016. However, as shown in Figure 8 below, the number of employees on the Tibah payroll increased to 470 in 2016. Tibah faced two challenges not anticipated prior to the sale of the airport. Firstly, they were soon confronted with the need to hire experienced non-Saudi employees at premium salaries to cover shortages in manpower; living in the city of Medina does not represent a sufficiently attractive incentive for non-Saudis, hence the need to offer higher salaries. Secondly, in the interim, there was a requirement to hire apprentices who would eventually be capable replacing the non-Saudis on completion of their training programmes.

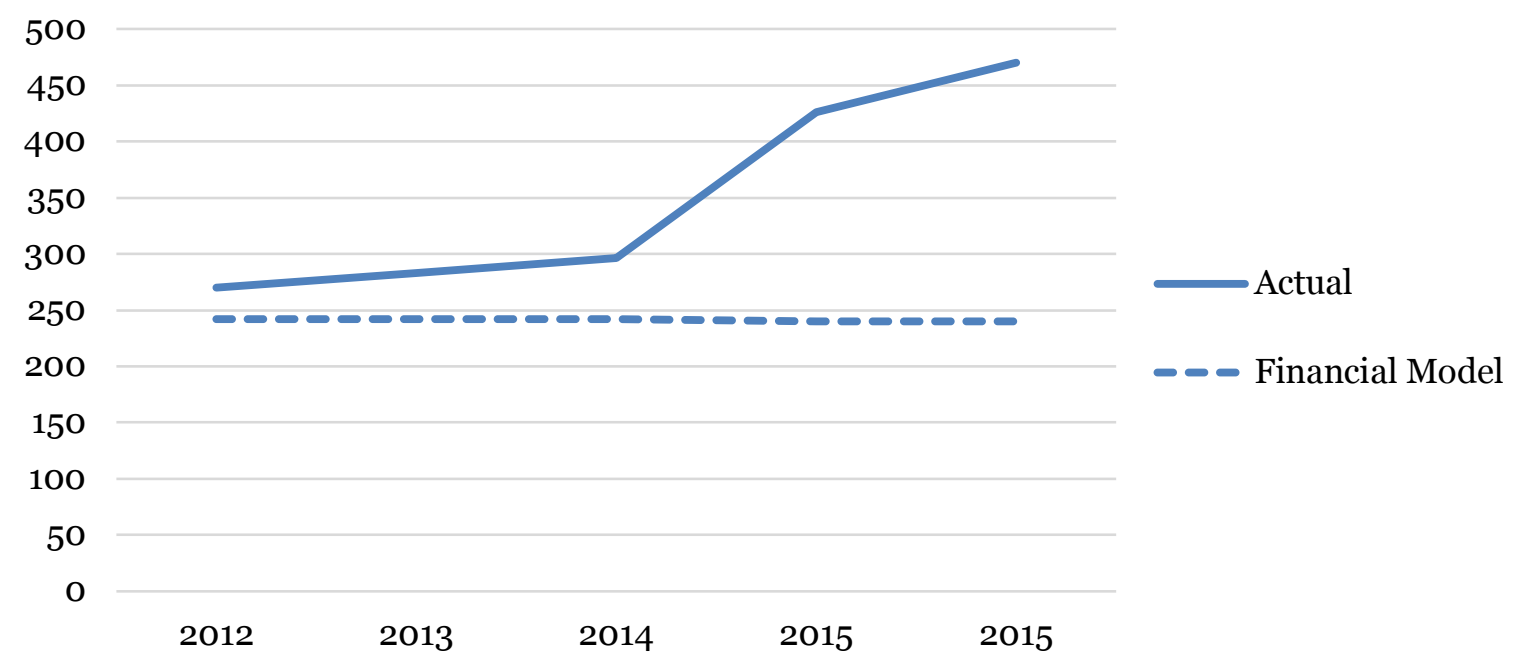

Figure 8 Actual and model staff employed by Medina Airport from 2012 to 2016.

Source: Compiled by Author from Tibah Airports Co. LTD unpublished yearly reports

Tibah was also required to absorb an unexpected increase in both electricity and water charges that resulted from a decision by the Government to raise tariffs set by utility providers; GACA refused to accept this as a case of force majeure. In total, the actual the cumulative amount incurred in operating expenditure exceeded the financial model forecasts by a factor close to $50 \%$. 


\subsubsection{Profitability}

We consider three indicators of profitability: EBITDAR, EBITDA and EBT². Figure 9 below shows that actual EBITDAR was broadly in line with that projected by the financial model. The better than expected revenue performance, appears to have offset the unexpected cost increases absorbed by Tibah as a result of GACA's unsolicited interventions.

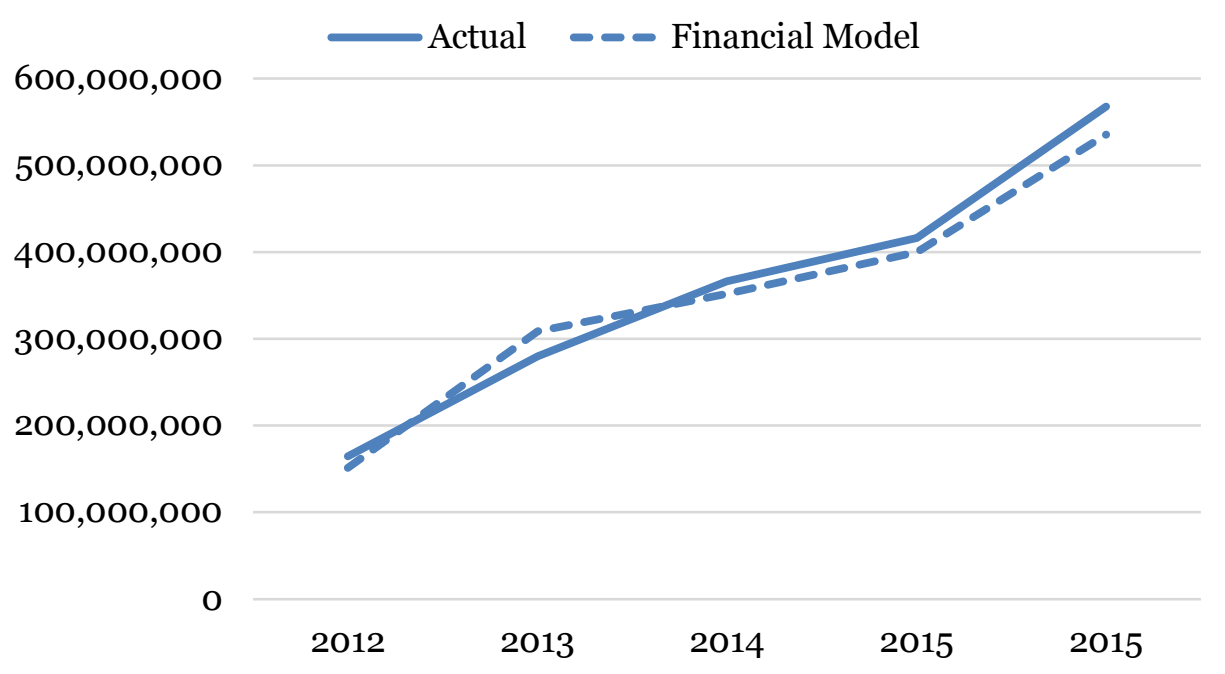

Figure 9 Medina Airport's EBITDAR (actual vs financial model) from 2012 to 2016

Source: Compiled by Author from Tibah Airports Co. LTD unpublished yearly reports

Figure 10 compares actual with forecast EBITDA. Here we incorporate the costs associated with payment of Tibah's concession fee to GACA. The concession fee at the outset was set at $54.5 \%$ of operating revenue; this appears to be quite high when compared to other international projects. For example, a similar turnover-based concession fee has been in operation at Canadian airports for many years. Toronto Pearson, which is the busiest hub, handling 44.3 million passengers in 2016, paid the equivalent of $17 \%$ of revenues as rental to the Canadian Federal Government (GTAA, 2016). London Luton airport in the United Kingdom, which was privatised under a 25year concession agreement in 1998, is also managed within a framework where the private operator pays a concession fee to the local municipal authority. The fee is perpassenger based and in financial year 2005, when it handled 9.2 million passengers, the total amount paid in concession charges to the local municipal authority was the equivalent of $21 \%$ of sales turnover.

\footnotetext{
${ }^{2}$ EBITDAR (Earnings before Interest, Tax, Depreciation, Amortisation and Rentals), EBITDA ((Earnings before Interest, Tax, Depreciation, Amortisation), EBT (Earnings before Tax)
} 


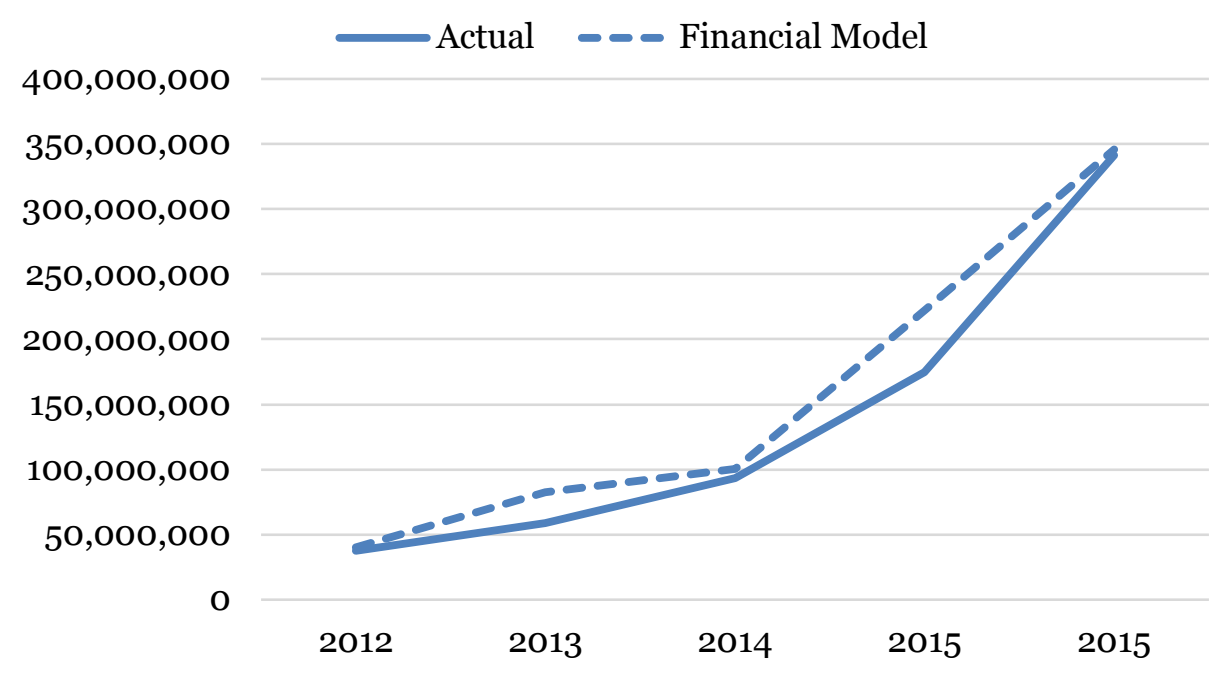

Figure 10 Medina Airport's EBITDA (actual vs financial model) from 2012 to 2016

Source: Compiled by Author from Tibah Airports Co. LTD unpublished yearly reports

The challenge of managing the airport with such a high concession fee appears to have prompted Tibah to re-negotiate a lower concession fee with GACA in 2014. They were successful in lowering the concession fee from $54.5 \%$ to $27 \%$ of operating revenues. This had the effect of improving what otherwise would have been a much lower level of EBITDA achieved in both 2015 and 2016. In 2015, EBITDA, under the original concession fee would have been SAR54.6 million compared to SAR174.9 million. We contrast actual and forecast EBIT in Figure 11 below.

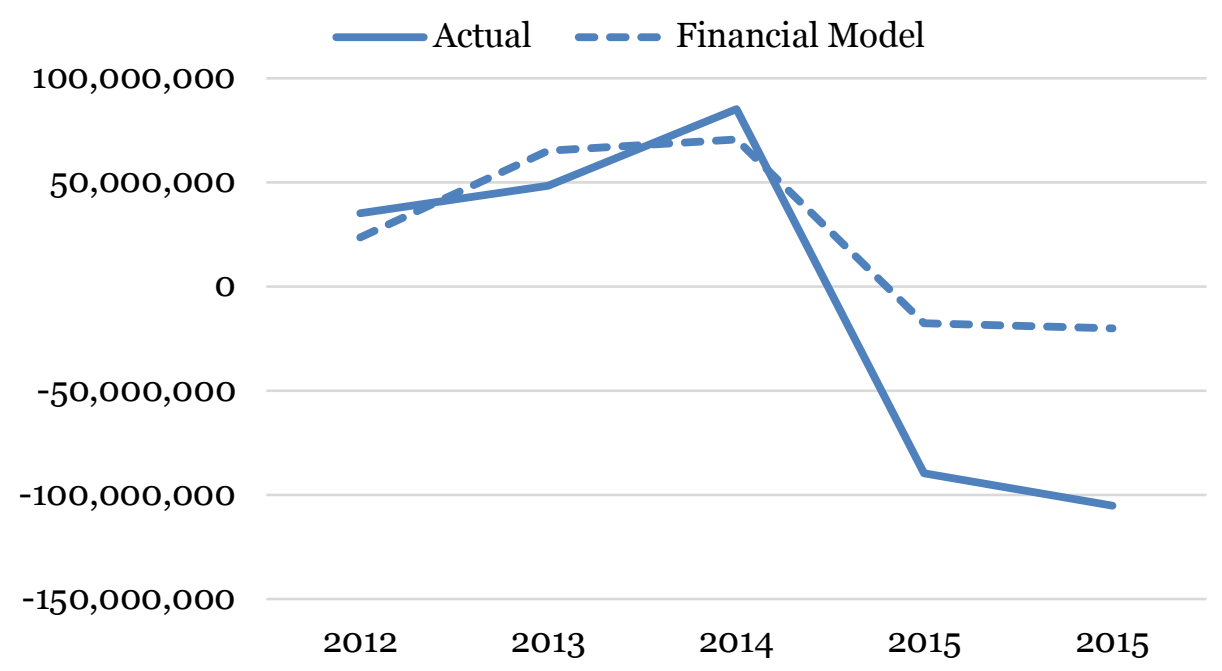

Figure 11 Medina Airport's EBIT (actual vs financial model) from 2012 to 2016.

Source: Compiled by Author from Tibah Airports Co. LTD unpublished yearly reports

What is apparent here is the effect of the opening of the new terminal in 2015. In particular, the effect of higher than predicted capital costs (depreciation charges and interest payments) associated with the new terminal. What is particularly relevant also is that Tibah was, in effect, forced to comply with and implement additional requests 
from GACA which were outside scope of the original BTO contract agreement. These additional requests included construction of a new temporary road access system, installation of an air-conditioning system in the walkway at the Hajj Plaza, the establishment of a temporary power supply substation, construction of Hajj terminal carrousels and the procurement of additional security machines. By 2016, the additional capital expenditure incurred by Tibah as a result of new obligations imposed by GACA amounted to US $\$ 35.1$ million, which represents approximately $3 \%$ of the original lifetime capital investment requirement (Table 7).

Table 7 GACA's additional requests after agreement (in US\$)

\begin{tabular}{ll} 
Item & Cost \\
\hline Temporary access road & 1.0 million \\
Walkway air-conditioning & 3.5 million \\
Temporary power supply substation & 13.5 million \\
Procurement of security machines & 14.5 million \\
Additional four carrousels at Hajj Terminal & 1.1 million \\
Other governmental agency requests & 1.1 million \\
Airport security buildings & 0.4 million \\
\hline
\end{tabular}

Source: Unpublished Tibah Airports Co Ltd. LTD letters to GACA

An additional amount of US\$6.65 million was invested which was related to operational activities but not accounted for in the financial model.

\section{Discussion and Conclusion}

In 2016, GACA announced that all international, regional and domestic airports in Saudi Arabia should be privatised by 2020 (GACA, 2016). Relative to the Middle East region, Saudi Arabia, thus far has been quite bold in terms of its ambitions to reform and modernise its airport sector and in the embrace of the public-private partnership (PPP) model of privatisation. Of all Middle-East states, the Kingdom has proved, thus far, to be the most enthusiastic proponent of PPP in the airport sector.

Medina airport was one of the first to be privatised in Saudi Arabia. Furthermore, the Medina transaction involved a greater degree of commercial risk transfer compared to the other transactions where GACA had decided to deploy relatively limited-scope management contracts. There are lessons to be learned from this experience if Saudi Arabia is to make a success of its airport privatisation ambitions. 
Tibah had under-estimated the growth in traffic volumes in their due-diligence modelling. Highly favourable market conditions, which to some extent was due to low cost carrier expansion and a more rigorous and commercial approach by the new operator to route development, appears to have produced higher than forecast traffic volumes. Indeed, their route development achievements were recognised in 2018 when the airport was awarded the Routes prize 3 for the best route development strategy in the 4 to 20 million annual passengers category within the Africa and Middle East region.

Stronger than expected traffic growth in turn generated higher revenues compared to that predicted by their due-diligence forecasting models. The new terminal built by Tibah, which opened in 2015, was also able to deliver a more extensive retail and commercial offer to passengers, achieving higher levels of sales penetration and spend and in turn delivering a larger proportion of revenue from higher margin nonaeronautical activities. Furthermore, there appears to have been a very obvious and noticeable improvement in passenger customer experience at Medina as the airport was rated as the best airport in the Middle East region in the 10-15 million passengers per year category by the widely respected and recognised ACI Airport Service Quality (ASQ) award programme in 2018. However, by international standards, there was a level of under-achievement in its ability to grow the proportion of revenues from nonaeronautical activities, especially when compared to airports of similar size in other regions. This suggests there are limitations imposed by the type of market serving the airport or that there are still opportunities for further improvement.

However, these achievements have been more than offset by significant underestimation of both operating costs which means that the overall returns achieved by the private operator have been much lower than forecast during the due-diligence period.

Firstly, Tibah under-estimated the human resource requirements as they struggled to recruit sufficient numbers of experienced personnel. Secondly, they had failed to anticipate a significant increase in personnel costs as a result of a change in GACA's legal status prior to receiving employees transferring from GACA. Thirdly, and

\footnotetext{
${ }^{3}$ Routes is the leading organiser of global and regional airline network planning and airport route development events. These bring together airports and airlines. The awards are agreed by panels of airline network planning specialists.
} 
perhaps more importantly, Tibah experienced challenges stemming almost entirely from a series of unilateral and unsolicited interventions by GACA after they had taken full management control of the airport. GACA insisted that Tibah finance and deliver additional capital expenditure and amend plans to levy concession charges on various third-party business operations at the airport. Both of these interventions had implications on the level of profitability of Tibah's Medina investment. There was no recourse within Saudi Arabia for Tibah to challenge GACA's interventions or to seek judicial review of their actions within the existing regulatory framework in Saudi Arabia.

Fundamentally, this problem largely stems from the fact that institutional arrangements and regulatory mechanisms with regard to the Kingdom's airport system remain poorly developed and may need reform if the state is to make a success of its proposed airport privatisation ambitions. ICAO recommends that statesponsored regulators are independent of both airports and airlines (ICAO, 2004). In the case of the Medina public-private partnership contract, GACA functions as both owner of the asset and regulator of airports. This arrangement is clearly problematic in the sense that firstly, there appears to be a very obvious conflict of interest and secondly both parties have no resource to independent arbitration in the event of a dispute. The concession agreement for Bangalore Airport in India, for instance, contains provision for independent arbitration and dispute resolution. Furthermore, the airport's aeronautical charges are controlled by a state-sponsored regulator AERA which is operationally and institutionally independent from the Ministry of Civil Aviation (owner of the airport concession).

Not only does BTO appear to be the most preferred PPP model but the Government is also expected to favour an enhanced role for foreign investors in managing airport concessions with Saudi-owned interests within bidding consortia expected to be limited to $25 \%$ (CAPA, 2016). Generating sufficient foreign investor interest in future transactions will be critical to the success of the Kingdom's airport privatisation ambitions. However, this will also depend to some extent on Saudi Arabia maintaining a reputation with international investors for being able to provide the necessary framework and establishing the required conditions for public private partnerships to succeed. Arbitrary interventions and the abrupt termination of contracts will not have enhanced Saudi Arabia's prospects for achieving successful public-private 
partnerships in its airport sector. Success will also to a large extent be dependent on the socio-political trajectory the Kingdom takes and also the significant human resource challenges that are expected to intensify in the years ahead.

\section{References}

ACI. (2017). Policy brief: Airport ownership, economic regulation and financial performance. 1. Montreal, Canada. Retrieved from http://www.aci.aero/media/ab5e7076-425c-4f13-b6a22e1a45a48a79/Up8q8Q/Publications/Airport Economics and Statistics/Policy Brief: Airport ownership, economic regulation and financial performance/airportownership-economic-regulation-and-financial-performance-2017.pdf.

Ali, J. (2004). GCC Insights: Oman's privatisation drive suffers setback. Gulf News. Retrieved from http://gulfnews.com/business/analysis/gcc-insights-oman-146-sprivatisation-drive-suffers-setback-1.337818

Alkhathlan, K. A. (2013). Contribution of oil in economic growth of Saudi Arabia. Applied Economics Letters, 20(4), 343-348. http://doi.org/10.1080/13504851.2012.703310

Assaf, A. (2010). The cost efficiency of Australian airports post privatisation: A Bayesian methodology. Tourism Management, 31(2), 267-273. http://doi.org/10.1016/j.tourman.2009.03.005

Barros, C., \& Dieke, P. (2007). Performance evaluation of Italian airports: A data envelopment analysis. Journal of Air Transport Management, 13(4), 184-191. http://doi.org/10.1016/j.jairtraman.2007.03.001

CAPA. (2016). Saudi airport privatisation ramps up as oil prices continue to fall. Retrieved from https://centreforaviation.com/insights/analysis/saudi-airportprivatisation-ramps-up-as-oil-prices-continue-to-fall-264772

Chen, Y. H., Lai, P. L., \& Piboonrungroj, P. (2017). The relationship between airport performance and privatisation policy: A nonparametric metafrontier approach. Journal of Transport Geography, 62(June), 229-235. http://doi.org/10.1016/j.jtrangeo.2017.06.005

Doganis, R. (1992). The airport business. London: Routledge.

Forsyth, Peter. (2002). Privatisation and regulation of Australian and New Zealand airports. Journal of Air Transport Management, 8(1), 19-28.

Forsyth, Peter. (2006). Airport Policy in Australia and New Zealand: Privatisation, Light Handed Regulation and Performance. Aviation Infrastructure Performance: A Study in Comparative Political Economy.

Fraport. (2014). Jeddah, Riyadh International Airport Management Support \& Training. Retrieved from http://www.fraport.com/content/fraport/en/misc/binaer/fraportgroup/fraport/fraport-worldwide1/consulting/references/airportstrategy/strategy-jeddah--riyadh/jcr:content.file/rs_stra_jed_ruh_online.pdf 
GACA. (2008). Statistical Yearbook 2008. Jeddah, Kingdom of Saudi Arabia. Retrieved from

https://gaca.gov.sa/scs/Satellite?blobcol=urldata\&blobkey=id\&blobtable=Mungo Blobs\&blobwhere $=1442842692891 \&$ ssbinary $=$ true

GACA. (2010). Statistical Yearbook 2010. Jeddah, Kingdom of Saudi Arabia. Retrieved from https://gaca.gov.sa/scs/Satellite?blobcol=urldata\&blobkey=id\&blobtable=Mungo Blobs\&blobwhere $=1442842692915 \&$ ssbinary $=$ true

GACA. (2015). Statistical Yearbook 2015. Jeddah, Kingdom of Saudi Arabia. Retrieved from https://gaca.gov.sa/scs/Satellite?blobcol=urldata\&blobkey=id\&blobtable=Mungo Blobs\&blobwhere $=1442848351231 \&$ ssbinary $=$ true

GACA. (2016). President of GACA Outlines Future Plans. Retrieved March 15, 2017, from https://gaca.gov.sa/web/en-gb/news/president-of-gaca-outlines-futureplans

GACA. (2018). Official Statement on King Abdul Aziz International Airport. Retrieved December 24, 2018, from https://gaca.gov.sa/web/en$\mathrm{gb} /$ news/gacanews-21022018-hfo1

General Authority for Statistics (2016). Demographic Research Bulletin 2016. Retrieved December 19, 2017, from https://www.stats.gov.sa/sites/default/files/endemographic-research-2016 1.xls

Gillen, D. (2011). The evolution of airport ownership and governance. Journal of Air Transport Management, 17(1), 3-13. http://doi.org/10.1016/j.jairtraman.2010.10.003

Graham, A. (2011). The objectives and outcomes of airport privatisation. Research in Transportation Business and Management, 1(1), 3-14. http://doi.org/10.1016/j.rtbm.2011.05.004

GTAA. (2016). Annual Report 2016. Toronto. Retrieved from http://world.honda.com/content/dam/site/world/investors/cq img/library/ann ual report/FY201603 annual report e 02.pdf

Hooper, P., Cain, R. \& White, S. (2000). The privatisation of Australia's airports. Transportation Research Part E: Logistics and Transportation Review, 36(3), 181-204. http://doi.org/10.1016/S1366-5545(99)00032-O

Humphreys, I. (1999). Privatisation and commercialisation. Changes in UK airport ownership patterns. Journal of Transport Geography, 7(2), 121-134. http://doi.org/10.1016/So966-6923(98)00038-6

IATA. (2016). IATA Forecasts Passenger Demand to Double Over 20 Years. Retrieved from http://www.iata.org/pressroom/pr/Pages/2016-10-18-02.aspx

ICAO. (2004). DOC 9626: Manual on the Regulation of International Air Transport Manual on the Regulation of International Air Transport (2nd Edition). Montreal, Canada: Secretary General. Retrieved from http://www.icao.int/Meetings/atconf6/Documents/Doc 9626 en.pdf 
Ison, S., Francis, G., Humphreys, I., \& Page, R. (2011). UK regional airport commercialisation and privatisation: 25years on. Journal of Transport Geography, 19(6), 1341-1349. https://doi.org/10.1016/j.jtrangeo.2011.06.005

Janecke, H. (2010). Practice papers Managing and delivering an airport privatisation programme: Case study of the Republic of Congo. Management, 5(1), 10-18.

Niemeier, H. M. (2002). Regulation of airports: The case of Hamburg airport- A view from the perspective of regional policy. Journal of Air Transport Management, 8(1), 37-48. http://doi.org/10.1016/So969-6997(01)00038-2

OPEC. (2017). Saudi Arabia facts and figures. Retrieved from http://www.opec.org/opec_web/en/about_us/169.htm

Oum, T. H., Adler, N. \& Yu, C. (2006). Privatization, corporatization, ownership forms and their effects on the performance of the world's major airports. Journal of Air Transport Management, 12(3), 109-121.

http://doi.org/10.1016/j.jairtraman.2005.11.003

Perelman, S., \& Serebrisky, T. (2012). Measuring the technical efficiency of airports in Latin America. Utilities Policy, 22, 1-7. http://doi.org/10.1016/j.jup.2012.02.001

Rikhy, A., Roberts, J. \& Cheung, S. (2014). Global Airport Privatisation: Trends, recent developments and challenges ahead. Journal of Airport Management, 8(4), 300-304. Retrieved from http://www.transecongroup.org/Transport Economist 25-3.pdf

TAV (2011). TAV Airports signed the contract for Medina Airport. Retrieved March 20, 2017, from http://www.tavhavalimanlari.com.tr/enEN/Pages/Announcements.aspx?aID=101

Tibah (2012). Tibah Airport Annual Report 2012. Tibah Airports Co. LTD unpublished raw data

Tibah (2013). Tibah Airport Annual Report 2013. Tibah Airports Co. LTD unpublished raw data

Tibah (2014). Tibah Airport Annual Report 2014. Tibah Airports Co. LTD unpublished raw data

Tibah (2015). Tibah Airport Annual Report 2015. Tibah Airports Co. LTD unpublished raw data

Tibah (2016). Tibah Airport Annual Report 2016. Tibah Airports Co. LTD unpublished raw data

Vasign, B., Haririan, M., (2003). An empirical investigation of financial and operational efficiency of private versus public airports. Journal of Air Transportation, 4(4), 91-110

Vogel, H. A. (2011). Do privatized airports add financial value? Research in Transportation Business and Management, 1(1), 15-24. https://doi.org/10.1016/j.rtbm.2011.05.002 
World Economic Forum. (2016). The Global Competitiveness Report (Vol. 5). http://doi.org/92-95044-35-5

Youssef, W. (2013). Case study: The privatisation of Madinah Airport, Saudi Arabia. Journal of Airport Management, 7(3), 231-236.

Zakrzewski, D. \& Juchan, R. (2006). Privatization impact and social disclosure: The case of Sydney airport. Journal of the Asia Pacific Centre for Environmental Accountability, 12(4), 4-12. 
2019-02-08

\section{A critical review of airport privatisation in the Kingdom of Saudi Arabia: Case study of Medina Airport}

Chaouk, Mohammed

Elsevier

Chaouk M, Pagliari R, Miyoshi C. A critical review of airport privatisation in the Kingdom of Saudi Arabia: Case study of Medina Airport. Case Studies on Transport Policy, Volume 7, Issue 2, June 2019, pp. 433-442

https://doi.org/10.1016/j.cstp.2019.02.001

Downloaded from Cranfield Library Services E-Repository 